\title{
Pengabdian Kepada Masyarakat untuk Siswa dan Pengelola Pusat Kegiatan Belajar Masyarakat di Kabupaten Bangkalan
}

\author{
Fitri Damayanti ${ }^{1)}$, Mohammad Syarief ${ }^{2)}$, Wahyudi Setiawan ${ }^{3)}$ \\ Prodi Manajemen Informatika, Fakultas Teknik, Universitas Trunojoyo Madura \\ ${ }^{1)}$ fitri2708@yahoo.com, ${ }^{2)}$ ayibnya@gmail.com, ${ }^{3)}$ wsetiawan@trunojoyo.ac.id
}

\begin{abstract}
Education is the basic right of every citizen. Education is needed to realize qualified Human Resources. One of the problems of education is lack of equal opportunity to get a decent education. Non Formal Education becomes an alternative solution. In this study built a school data management information system. The information system consists of five levels of users namely the main administrator, school administrators, teachers, students and the public. The data is processed in the form of school data, facilities, managers, teachers, students and general information.There is a history of starting students entering until students graduate. In addition there is also a Satuan Acara Pembelajaran (SAP) which informs the materials that must be submitted in the learning process. This information system will be equipped with a learning application of the National Exam for High School student. It is consisting of materials and multiple choice exam exercises for economic subjects, sociology, Indonesian, English, Geography and Mathematics. The data and information processed comes from the Dinas Pendidikan Kabupaten Bangkalan and the program organizer of the paket $\mathrm{C}$. While the learning application material comes from certain high school textbooks. It is expected that the school data management information system and learning applications for students of paket $\mathrm{C}$ can improve the quality of non formal school education in Bangkalan district.
\end{abstract}

Keywords: school information system, learning application, pusat kegiatan belajar mengajar (PKBM)

\begin{abstract}
ABSTRAK
Pendidikan merupakan hak dasar setiap warga negara. Pendidikan dibutuhkan untuk mewujudkan Sumber Daya Manusia (SDM) yang berkualitas. Salah satu permasalahan pendidikan yaitu kurangnya pemerataan kesempatan untuk mendapatkan pendidikan yang layak. Pendidikan Non Formal menjadi alternatif solusi penyelenggaraan pendidikan. Pada penelitian ini dibangun sebuah sistem informasi pengelolaan data sekolah. Sistem informasi terdiri dari lima tingkat user yaitu administrator utama, administrator sekolah, guru, siswa dan umum. Data yang diolah berupa data sekolah, fasilitas, pengelola, guru, siswa serta informasi umum. Untuk data siswa terdapat history mulai siswa masuk hingga siswa lulus. Selain itu terdapat pula Satuan Acara Pembelajaran (SAP) yang menginformasikan materi-materi yang harus disampaikan pada proses belajar mengajar. Sistem informasi ini akan dilengkapi dengan aplikasi pembelajaran untuk Ujian Nasional bagi siswa kejar paket $\mathrm{C}$ yang terdiri dari materi dan latihan ujian pilihan ganda untuk mata pelajaran ekonomi, sosiologi, bahasa Indonesia, bahasa Inggris, Geografi dan Matematika. Data dan informasi yang diolah berasal dari Dinas Pendidikan Kabupaten Bangkalan serta penyelenggara program kejar paket. Sedangkan materi aplikasi pembelajaran berasal dari buku-buku pelajaran tertentu setingkat SMA. Diharapkan sistem informasi pengelolaan data sekolah dan aplikasi pembelajaran untuk siswa kejar paket $\mathrm{C}$ ini dapat meningkatkan mutu pendidikan sekolah non formal di wilayah kabupaten Bangkalan.
\end{abstract}

Kata Kunci : sistem informasi sekolah, aplikasi pembelajaran, pusat kegiatan belajar mengajar (PKBM)

\section{PENDAHULUAN}

Pendidikan merupakan hak dasar setiap warga negara. Pendidikan dibutuhkan untuk mewujudkan Sumber Daya Manusia (SDM) yang berkualitas. SDM yang berkualitas dapat meningkatkan daya saing sebuah negara. Salah satu permasalahan pendidikan di negeri ini yaitu kurangnya pemerataan kesempatan untuk mendapatkan pendidikan yang layak. Disisi lain, pemerintah sebenarnya telah memiliki program pendidikan dasar sembilan tahun dan akan 
dilanjutkan untuk program duabelas tahun. Program ini masih belum mampu untuk menjangkau pemerataan pendidikan yang layak di seluruh negeri.

Kabupaten Bangkalan sebagai salah satu wilayah daerah tertinggal di Indonesia memiliki model pendidikan yang khas. Wilayah ini, sebagaimana wilayah lain di pulau Madura, sebagian besar masyarakatnya memperoleh pendidikan melalui pondok pesantren (ponpes). Namun keberadaan ponpes-ponpes yag tersebar di hampir setiap kecamatan belum mampu untuk menyelenggarakan pendidikan untuk setiap warga yang ada. Pada tahun 2013, tercatat bahwa penduduk yang tidak tamat SD mencapai 57,73\%. Proporsi tingkat pendidikan Kabupaten Bangkalan ditunjukkan pada Tabel 1

Tabel 1. Proporsi Tingkat Pendidikan Kabupaten Bangkalan 2013

\begin{tabular}{cc}
\hline Status Pendidikan & Prosentase \\
\hline Tidak pernah Sekolah & $17,97 \%$ \\
Tidak/Belum Tamat SD & $57,73 \%$ \\
Tamat SD & $6,12 \%$ \\
Tamat SMP & $5,09 \%$ \\
Tamat SMA & $5,38 \%$ \\
Tamat SMK & $0,47 \%$ \\
Tamat Diploma & $5,18 \%$ \\
Tamat Sarjana & $1,55 \%$ \\
\hline
\end{tabular}

(Sumber : kementrian P\&K, 2013)

Alternatif solusi untuk menyelesaikan permasalahan tersebut yaitu adanya pendidikan Non Formal yang dapat terjangkau oleh semua lapisan masyarakat. Pendidikan tersebut yaitu Kejar Paket. Kejar Paket A untuk setara Sekolah Dasar, Kejar Paket B untuk setara Sekolah Menengah Pertama dan Kejar Paket C untuk setara Sekolah Menengah Atas. Penyelenggara program kejar paket di kabupaten Bangkalan terdiri dari dua jenis yaitu Pusat Kegiatan Belajar Masyarakat (PKBM) yang didanai secara swadaya oleh masyarakat dan Ponpes. Terdapat lima belas PKBM dan tiga belas Ponpes yang menyelenggarakan program kejar paket (Dinas Pendidikan Bangkalan, 2013). Untuk tahun 2017, diprediksi bahwa jumlah PKBM juga turut naik sebagai wujud masyarakat melakukan swadaya untuk memajukan pendidikan.

Tujuan dari penyelenggaraan pendidikan kejar paket yaitu mendidik siswa dengan mutu dan kualitas setara dengan sekolah formal. Namun pada faktanya, masih terdapat kendala yang membuat standar sekolah kejar masih tertinggal dibandingkan sekolah formal . Permasalahan tersebut diantaranya proses belajar mengajar yang tidak sesuai standar, pengelolaan data \& informasi yang masih manual serta kekurangan fasilitas pendukung untuk proses belajar mengajar.

Untuk memberikan solusi pada permasalahan tersebut dibuatlah sebuah sistem informasi yang dapat melakukan pengorganisasian data dan informasi serta dapat melakukan pengaksesan lebih mudah dimanapun dan kapanpun data diperlukan untuk diketahui. Pada proposal penelitian ini akan dibuat sebuah sistem informasi tentang pengelolaan data sekolah kejar paket. Sistem informasi ini berisi tetang aturan-aturan prosedural berupa Standar Operasional Prosedur (SOP) proses belajar mengajar, jadwal tahunan proses belajar mengajar, GBPP/SAP mata pelajaran, data pengelola, data guru, data karyawan, data siswa, data alumni, data fasilitas yang dimiliki. Pada sistem informasi sekolah terdapat pula history hasil evaluasi siswa mulai dari awal masuk sekolah hingga lulus. Selain itu akan dibuat sebuah aplikasi pembelajaran persiapan Ujian Nasional khusus bagi siswa kejar paket C. Aplikasi ini untuk jurusan IPS, karena semua penyelenggara kejar paket $\mathrm{C}$ di Kabupaten Bangkalan hanya memiliki jurusan tersebut. Aplikasi ini terdiri dari pembelajaran enam mata pelajaran yaitu Ekonomi, Geografi, Bahasa Indonesia, Bahasa Inggris, Matematika dan Sosiologi. Aplikasi ini dibuat untuk memudahkan siswa mengakses materi alternatif dan melakukan proses pembelajaran lebih mudah, karena dibuat dengan beragam animasi. 
Diharapkan dengan adanya sistem informasi ini, kemudahan akan didapatkan dalam permasalahan pengolahan data. Sistem juga mampu menghasilkan data lebih akurat dan menghindarkan dari kesalahan pengolahan informasi. Selain itu penelitian ini diharapkan memberikan alternatif pembelajaran khususnya bagi siswa kejar paket $\mathrm{C}$.

\section{METODE PELAKSANAAN}

Metode pelaksanaan atau tahapan yang dilakukan dalam program pengabdian masyarakat ini ditunjukkan pada Gambar 1

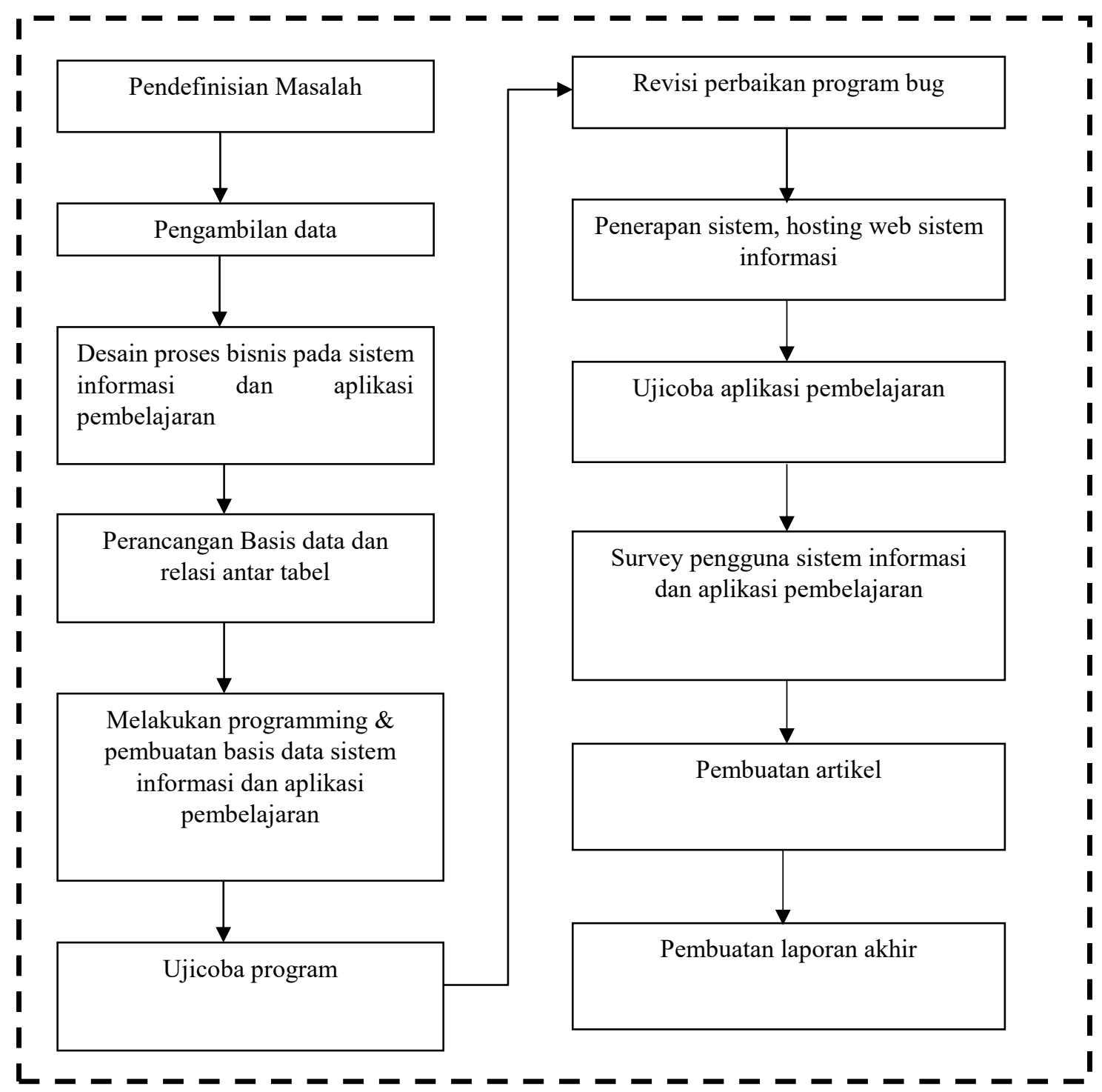

Gambar 1. Metode Pelaksanaan

\section{Metode pelaksanaan}

Beberapa tahapan pelaksanaan pengabdian kepada masyarakat dapat diurutkan sebagai berikut, yaitu :

1. Identifikasi Masalah

Identifikasi merupakan tahapan pendefinisian sistem, tujuan, perumusan masalah, sumber daya, data yang digunakan serta biaya untuk dapat membangun sistem.

2. Pengumpulan Data 
Data yang digunakan untuk percobaan, didapatkan dari Dinas pendidikan Kabupaten Bangkalan

3. Desain proses bisnis

Proses bisnis yang akan terjadi pada pembangunan sistem informasi harus dilakukan identifikasi terlebih dahulu.

4. Perancangan basis data dan relasi antar tabel

Setelah proses bisnis dilakukan, selanjutnya perancangan basisdata dan relasi antar tabel perlu untuk dijelaskan.

5. Pembuatan program

Sistem dibangun dengan user friendly. Seorang pengguna akan dengan mudah mengoperasikan aplikasi yang dibuat.

6. Ujicoba sistem

Ujicoba sistem dilakukan dengan melibatkan stakeholder yang terlibat pada sekolah

7. Revisi program

Revisi program dilakukan untuk memperbaiki kesalahan-kesalahan pada program yang telah diujicobakan

8. Penerapan sistem informasi dengan hosting web

Penerapan sistem informasi dan implementasinya. Web sistem informasi yang telah dibangun selanjutnya dilakukan hosting.

9. Ujicoba aplikasi pembelajaran

Ujicoba aplikasi pembelajaran pada siswa kejar paket C

10. Survey pengguna sistem informasi dan aplikasi pembelajaran

Survey dibuat untuk mengetahui tingkat kepuasan serta pentingnya aplikasi yang dihasilkan dapat diterapkan.

11. Penarikan kesimpulan dan penulisan artikel

Kesimpulan didapatkan dari hasil pengujian sistem, kelayakan sistem didapat dari survey. Penulisan artikel akan dilakukan dengan merangkum proses-proses yang terjadi pada metodologi penelitian.

\section{HASIL DAN PEMBAHASAN}

\section{Hasil}

Pada kegiatan IbM ini terdapat dua kegiatan utama yaitu perbaikan manajemen administrasi dengan membuat sistem informasi sekolah berbasis web untuk pengelola PKBM dan pembuatan aplikasi pembelajaran untuk siswa.

\section{Sistem Informasi berbasis web}

Secara umum sistem informasi sekolah terdiri dari 3 (tiga) bagian yaitu sistem informasi penilaian (Assessment Information Systems), sistem manajemen pembelajaran (Learning Management Systems) dan Sistem informasi administrasi (Administration System Information). Sistem informasi penilaian berisi tentang history hasil evaluasi belajar tiap-tiap siswa. Sistem informasi pembelajaran berisi tentang materi pembelajaran di kelas. Sedangkan Sistem Informasi Administrasi berisi tentang data-data umum seperti data siswa, data guru, data karyawan, data keuangan, jadwal pembelajaran dan informasi umum. Gambar 2 sampai dengan gambar 4 merupakan Antar muka sistem informasi yang dibangun. Aplikasi sistem informasi telah dilakukan hosting dan dapat diakses melalui www.ibmpkbmbangkalan.com 


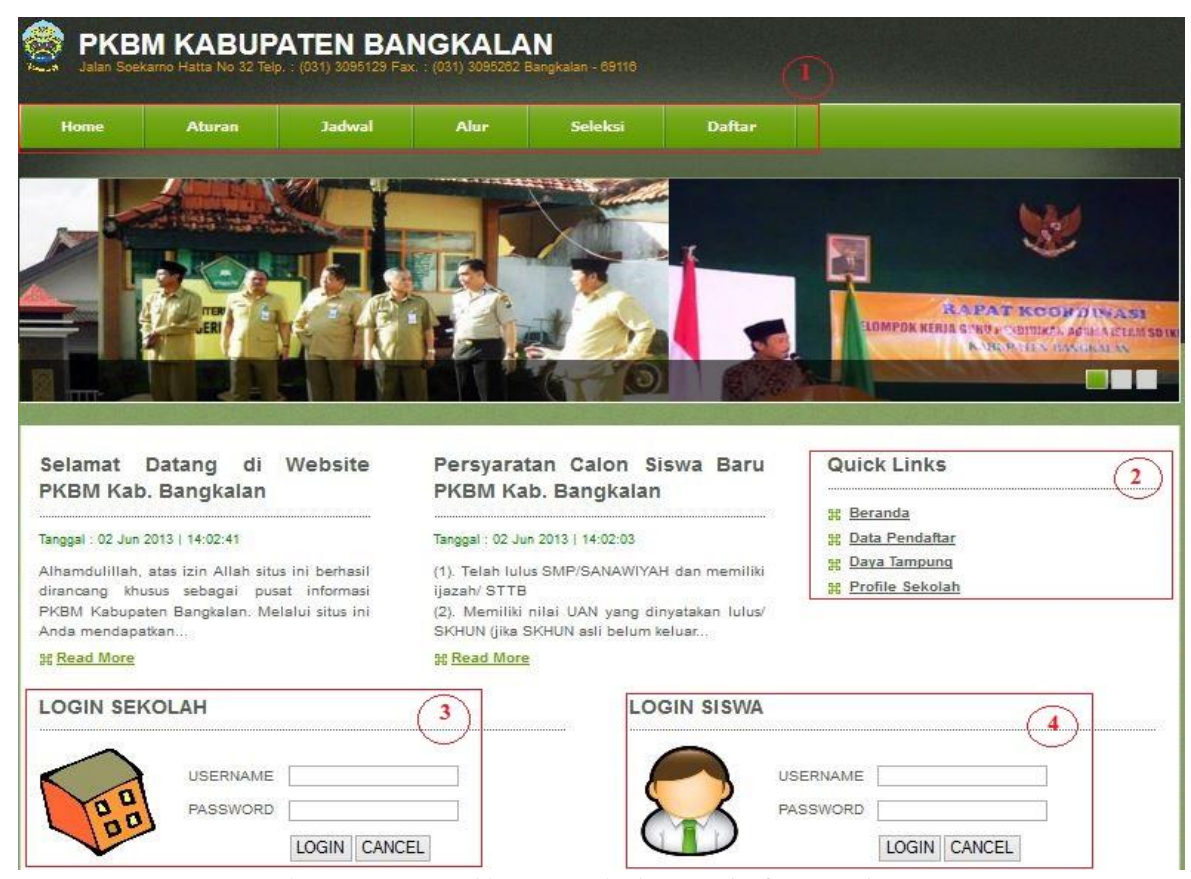

Gambar 2. Tampilan awal sistem informasi PKBM

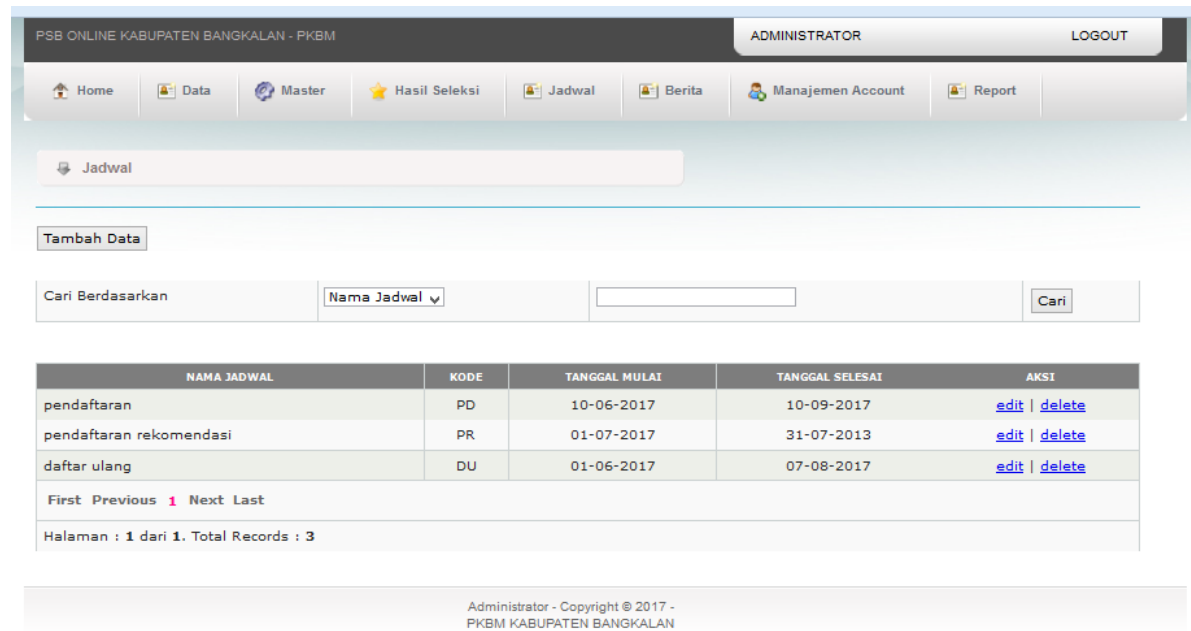

Gambar 3. Form Manajemen Data

\section{\begin{tabular}{l|l|l|l} 
Data Siswa & Data Sekolah & Data Kecamatan & Data Guru
\end{tabular}}

\section{Data siswa}

\section{Excel PDF cetak}

ID siswa Nama Alamat $\quad$ Kecamatan JenKeltempat Lahirtgl Lahir Telp Asal Sekolah ID User ID Sekolah

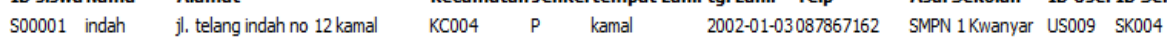

S00002 budi jl salakno $34 \quad$ KCO04 L kamal 2002-02-010313011069 SMPN 1Modung US010 SK004

S00003 dadang jil jambu $13 \quad$ KCO04 L kamal 2003-07-050313011313 SMP Al KhatbiyahUS011 SK005

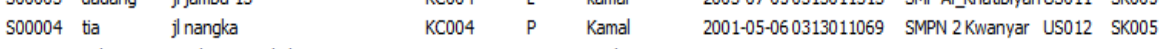

S00007 indri Modung Bangkalan KCO12 P $\quad$ Modung 2001-01-010852328679915MP Kwanyar 2 US015 SK001

S00006 syafa Kwanyar Bangkalan $\quad$ KC007 $\quad \mathrm{P} \quad$ Bangkalan 1994-03-01085232867991 SMP Alhatbiyah US014 SK001 S00005 Musyarofah Karang Anyar Kwanyar BangkalanKC007 P Bangkalan 1993-11-10 085232867993 SMPN 1 Kwanyar US013 SK002 (c) PKBM Kabupaten Bangkalan

Gambar 4. Hasil Report dari data siswa 


\section{Aplikasi Pembelajaran}

Aplikasi pembelajaran yang dibangun berisi tenatang pembelajaran enam mata pelajaran yaitu Ekonomi, Geografi, Sosiologi, Bahasa Inggris, Bahasa Indonesia dan Matematika. Aplikasi pembelajaran terdiri dari materi-materi yang diambil dari buku paket sekolah. Materi pembelajaran terdiri dari teks, gambar, suara dan video. Selain materi terdapat pula latihan soal ujian. Latihan berupa pertanyaan pilihan ganda yang dapat diketahui skor nilai secara langsung berdasarkan jawaban yang dipilih oleh user. Gambar 5 sampai dengan 7 merupakan antar muka dari aplikasi pembelajaran.

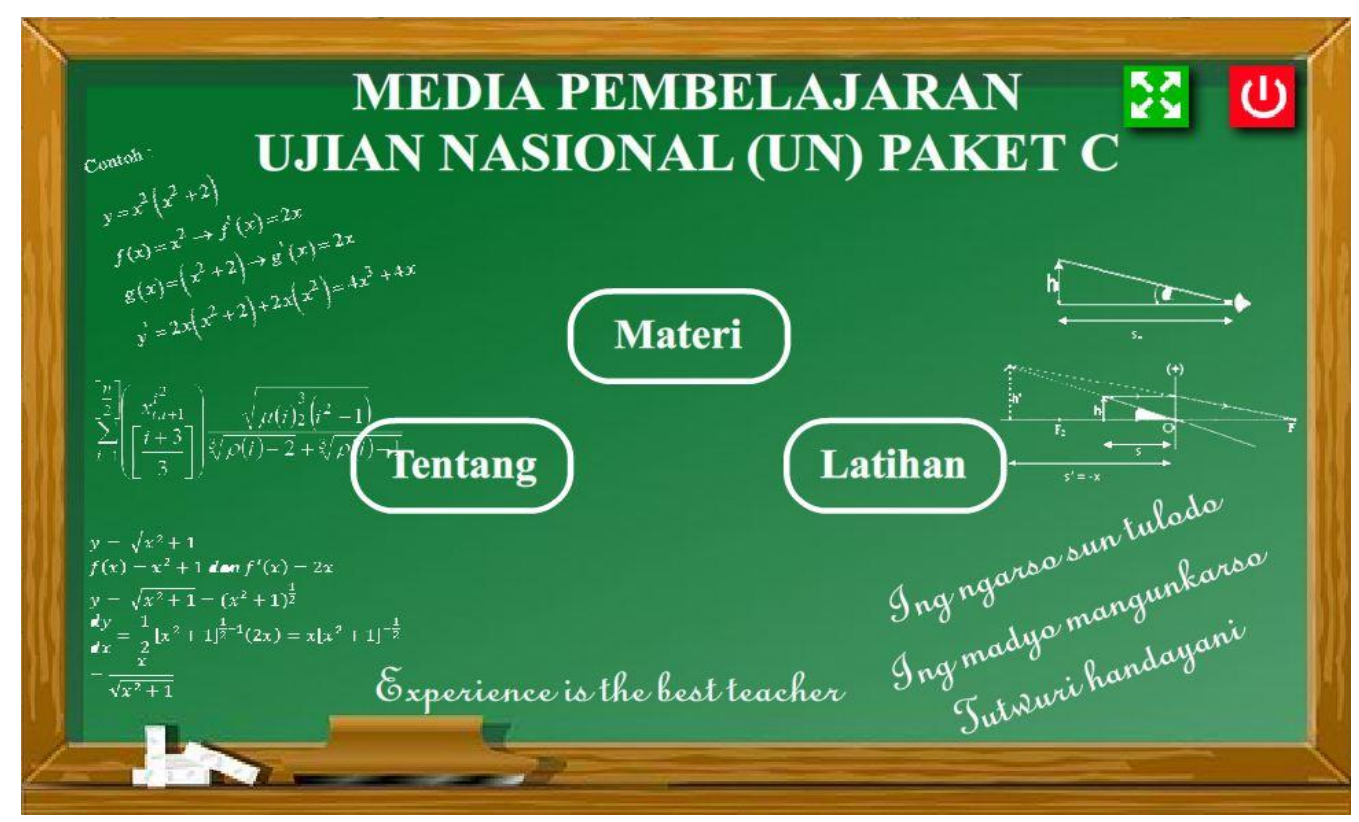

Gambar 5. Antarmuka awal aplikasi pembelajaran

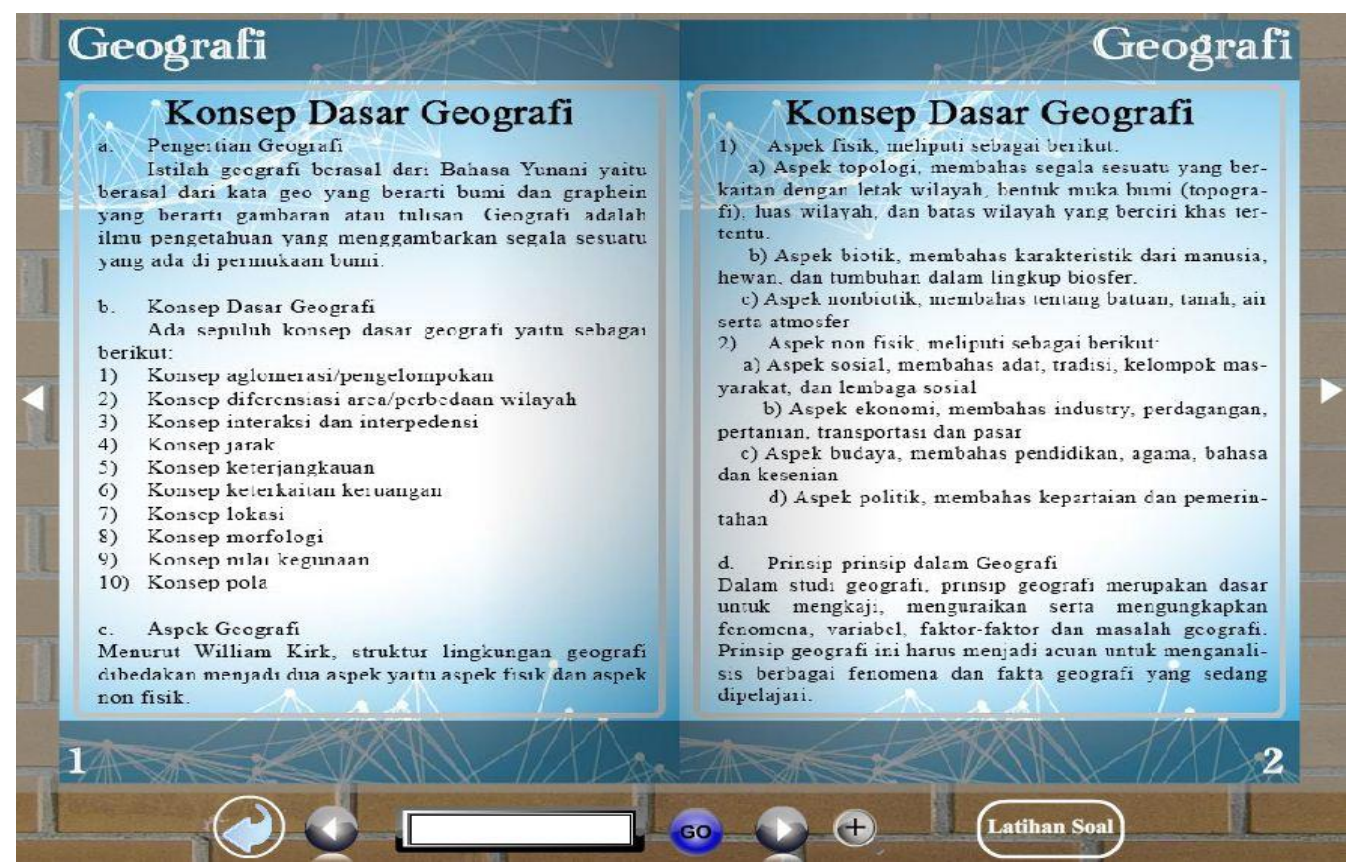

Gambar 6. Materi pembelajaran 


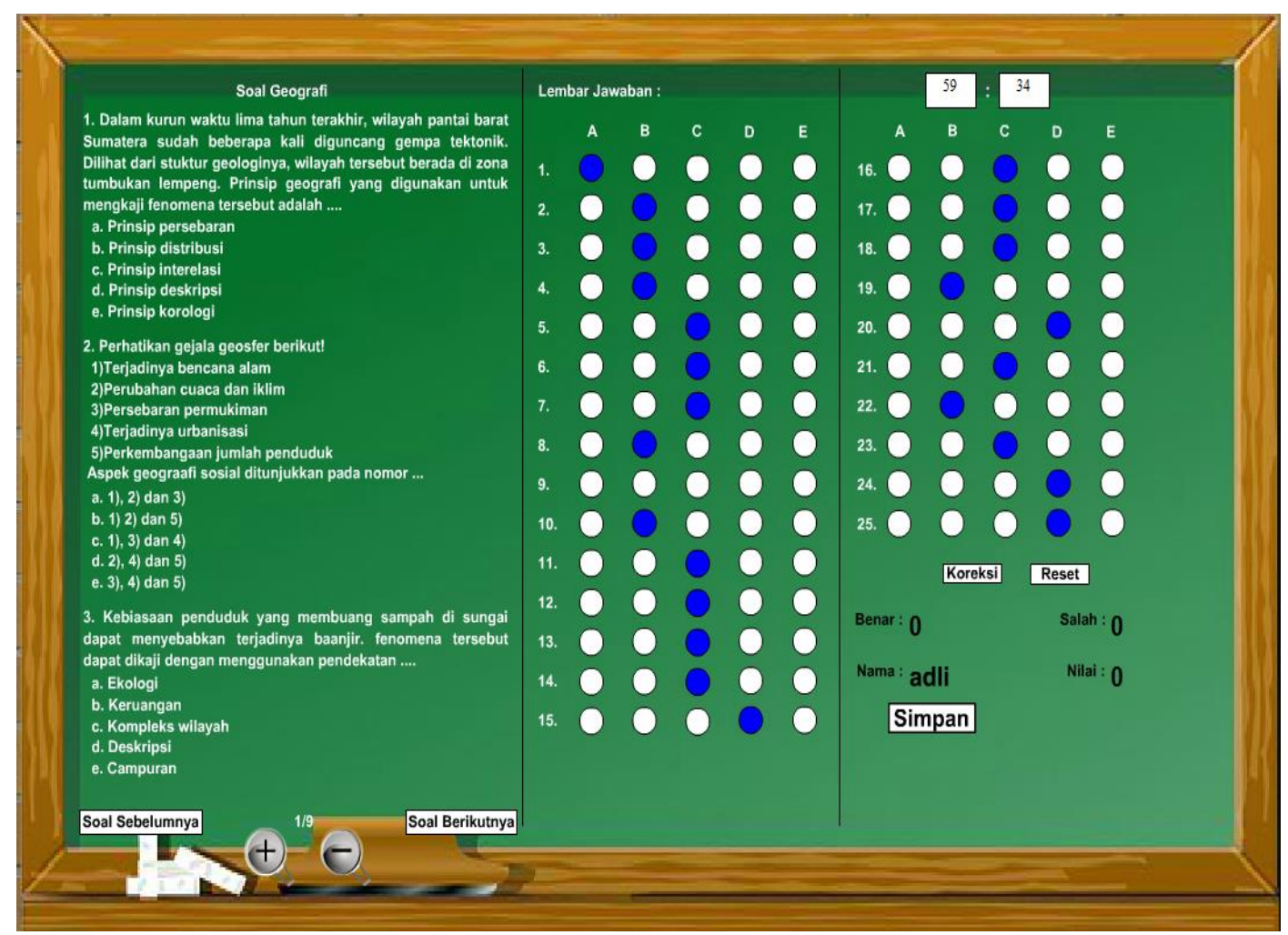

Gambar 7. Latihan soal pilihan ganda

\section{Pembahasan}

Kedua hasil IbM dilakukan hingga empat kali workshop. Hal tersebut untuk membiasakan peserta dengan aplikasi. Namun terdapat beberapa kendala untuk melakukan ini yaitu rendahnya kualitas pengelola terhadap teknologi informasi serta dukungan sarana prasarana kurang memadai. Kedua hasil IbM selanjutnya dilakukan kuesioner terhadap pengelola dan siswa PKBM. Kuesioner melibatkan 30 (tiga puluh) responden. Kuesioner terdiri dari sepuluh pernyataan utuk sistem informasi dan aplikasi pembelajaran. Jawaban diberikan pilihan dari skala 0 (nol) hingga 5 (lima). Skala menunjukkan arti mulai dari kurang sekali, kurang, cukup, baik dan baik sekali. Pernyataanpernyataan tersebut yaitu :

1. Aplikasi mudah dipahami

2. Aplikasi sesuai dengan kebutuhan

3. Aplikasi bermanfaat

4. Aplikasi memudahkan pekerjaan

5. Aplikasi membuat pekerjaan lebih efektif

6. Lebih mudah mendapatkan informasi tentang data

7. Memudahkan mempelajari materi UNAS

8. Aplikasi menambah pengetahuan tentang Teknologi Informasi

9. Memotivasi untuk belajar

10. Aplikasi tepat guna

Hasil kuesioner menunjukkan bahwa responden menyatakan aplikasi yang dihasilkan pada program Pengabdian Kepada Masyarakat ini ditunjukkan pada tabel 2. 
Tabel 2. Prosentase hasil kuesioner terhadap aplikasi hasil IbM

\begin{tabular}{cccc}
\hline No & Kriteria & $\begin{array}{c}\text { Jumlah } \\
\text { Pilihan }\end{array}$ & Presentase \\
\hline 1. & Baik sekali & 46 & $15,4 \%$ \\
2. & Baik & 110 & $36,6 \%$ \\
3. & Cukup & 100 & $33,4 \%$ \\
4. & Kurang & 34 & $11,3 \%$ \\
5. & Kurang sekali & 10 & $3,3 \%$ \\
\hline & Total & 300 & $100 \%$ \\
\hline
\end{tabular}

\section{KESIMPULAN}

Program Iptek bagi Masyarakat (IbM) siswa dan pengelola Pusat Kegiatan Belajara Masyarakat telah selesai dilakukan dengan menghasilkan :

1. Aplikasi sistem informasi PKBM

2. Aplikasi pembelajaran

3. Hasil kuesioner menunjukkan prosentase tertinggi yaitu aplikasi dinilai baik sebesar $36,6 \%$

Hasil aplikasi perlu untuk diterapkan secara berkelanjutan pada institusi PKBM. Aplikasi dapat dikembangkan dengan menambah fitur-fitur yang dibutuhkan oleh stakeholder PKBM, sehingga aplikasi dapat tepat guna dan bermanfaat khususnya pada bidang pengolahan administrasi data dan materi pembelajaran sekolah.

\section{UCAPAN TERIMA KASIH}

Kami sampaikan terima kasih kepada DRPM DIKTI yang telah membiayai kegiatan pengabdian masyarakat ini. Kami haturkan terima kasih pula pada Lembaga Penelitian dan Pengabdian Universitas Trunojoyo atas kesempatan untuk melakukan kegiatan pengabdian masyarakat IbM Siswa dan Pengelola Pusat Kegiatan Belajar Masyarakat (PKBM)

\section{DAFTAR PUSTAKA}

Kementrian Pendidikan dan Kebudayaan, (2015), Profil Pendidikan Dasar dan Menengah, Pusat Data dan Statistik Pendidikan, Jakarta

Dinas Pendidikan Kabupaten Bangkalan, (2013), Data penyelenggara ujian Kejar Paket C, Bangkalan

Plant, Y., A., Addysg and Sgiliau, (2007), Guidance for School Information System, Department for Children, Education, Lifelong Learning and Skills, Lywodraeth, Wales

Kamile, D., (2006), School Management Information Systems in Primary Schools, The Turkish Online Journal of Educational Technology - TOJET April 2006 ISSN: 1303-6521 volume 5 Issue 2 Article 6

Fahanani I., Ulinuha, A., \& Yuliana, I., (2013), Sistem Informasi Sekolah di SMP Negeri 2 Sukoharjo berbasis desktop, Surakarta

Breiter, A., \& Light, D., (2006), Data for School Improvement: Factors for designing effective information systems to support decision-making in schools. Educational Technology \& Society, 9 (3), 206-217.

, (2015), School Management Information System User Guide for MIS Client, Department of School Education, Haryana, India 